\title{
Cooperative Family Registries for Breast and Colorectal Cancer Studies
}

National Cancer Institute

\section{Source}

National Cancer Institute. Cooperative Family Registries for Breast and Colorectal Cancer

Studies. NCI Thesaurus. Code C15953.

Cooperative family registries specific for breast and colorectal cancer studies. 